\title{
ICT Infrastructure, ICT Competencies, and Teachers' Workload: Critical Factors that Influence Social Studies Teachers' Integration of Technology in the Kwahu West Municipality of Ghana
}

\author{
AFUTOR, Philemon \\ Christ Apostolic University College, Department of Basic Education, Kumasi, Ashanti Region, Ghana
}

\begin{abstract}
The purpose of this study was to investigate factors that influence basic school social studies teachers' integration of technology in the teaching of Social Studies in schools within the Kwahu-West Municipality of Ghana. The study sought to address the following objectives: To what extent do ICT infrastructure, teachers' ICT competence and work load influence basic school social studies teachers' integration of technology in their lessons in the Kwahu-West Municipality of Ghana? The study was a descriptive survey. Proportional simple random technique was employed in selecting sample size of eighty-one (81) Junior High School social studies from 46 public basic schools within the Kwahu West Municipality of Ghana. The data for the study was collected using questionnaires to solicit responds from the teachers. A Cronbach Alpha value of .860 was obtained for the reliability of the items on the questionnaires. The data of the study was analyzed using Multiple Regression Analysis which established Rsquare $\left(\mathrm{R}^{2}\right)$ value of 0.7090 at 0.05 alpha level of significance. From the analysis, it was established that basic school teachers' integration of technology in their social studies lessons were heavily influenced by the ICT infrastructure of their school, their ICT competence and their workloads in terms of number of periods they handled a week and other co-curriculum activities they have been asked to engage in. It was recommended that Government through Ministry of Education and other relevant stakeholders should ensure the provision of art-ofcraft ICT infrastructure in basic schools within the municipality coupled with organization of regular in-service programs for teachers to upgrade their knowledge on technology integration.
\end{abstract}

Keywords: Basic School, Kwahu West, Technology, Workload, Social Studies, Integration.

DOI: $10.7176 / \mathrm{JEP} / 11-14-08$

Publication date:May $31^{\text {st }} 2020$

\section{Introduction}

The importance of Information Communication Technologies (ICTs) in teaching and learning can never go unnoticed. Governments all over the world are changing or reviewing their curriculums to lay more emphasis on ICT education in appreciation of the positive impacts of ICT on the socio-economic development of its people. The case of Ghana is therefore not different. The 2007 education reform for instance emphasized high premium on technical/ vocational education and training and incorporated ICTs into the country's pre tertiary curriculum. In quest to see the fruition of this, the ministry of education implemented a number of policies and programs interventions which are aimed at the integration of ICTs into education to facilitate effective teaching, learning and management through the provision of computer labs, internet and network connectivity to schools, supply of laptops to teachers and students and capacity development of teachers in using these laptops to improve the quality of their teaching.

In the forward to the current ICT in Education Policy in January 2009, the Hon. Minister of education noted, among other things that:

"..... it is the government's desire that through the deployment of ICT in education, the practice of traditional memory-learning will be transformed to education that stimulate thinking and creativity necessary to meet the challenges of the $21^{\text {st }}$ century". (ICT in Education Policy 2015 p9).

It is clear that the Ministry of Education sees the integration of ICT into education not as an end in itself but a tool or means by which students learning and teaching in the $21^{\text {st }}$ century can be improved. This is in agreement with Papaioannom and Charalambous (2011) cited in Luhombo(2015) which stressed that ICT in school can motivate students, stimulate their interest, increase their confidence and self-esteem, increase their creativity, enhance their critical thinking and increase their attainment among other benefits. All of these give us much reason to agree with the notion that the world has indeed entered the industrial revolution 4.0, a concept introduced by Prof. Kalus Schwab in his book entitled the fourth industrial revolution. According to Prof. Schwab, the industrial revolution 4.0 is an era that has fundamentally changed human life and work. This era is marked by the rapid development of information technology as the main base that has big influence in every line of human life, education, economics, social, and various other field of life. The advancement of new technologies that integrate the physical, digital and biological worlds affects all disciplines including the field of education. (Schwab 2015) 
The $21^{\text {st }}$ century teaching and learning paradigm appropriately promote and shift teaching and learning to learner centred environment. (Hooper, S.\& Rieber, L. P. 1995). The deployment of technology/ICT has enabled new ways of teaching and learning from "content-centred" to "competence-based". Within the $21^{\text {st }}$ century, students are preoccupied and interested in technological/ICT processes, applications and resources. To enable students' function effectively around these technological resources, teachers need to instill in students the needed competencies and skills to positively use ICT resources innovatively in addressing societal problems and aspirations. By doing so, teachers need to be equipped with the requisite knowledge, skills and competencies to effectively blend technology with content and pedagogy (Dunmire, 2010).

Mishra and Koehler (2006) recently introduced the union of three different types of knowledge as representative of what teachers need to know, "technological pedagogical content knowledge". Technological pedagogical content knowledge (TPACK) is an understanding that emerges from interactions among content, pedagogy, and technology knowledge. TPACK is the basis of effective teaching with technology, requiring an understanding of the representation of concepts using technologies; pedagogical techniques that use technologies in constructive ways to teach content; knowledge of what makes concepts difficult or easy to learn and how technology can help redress some of the problems that students face; knowledge of students' prior knowledge and theories of meta-physical knowledge (Koehler \& Mishra, 2009).

To meet this challenge, Social Studies teaching and learning in Junior High Schools in Ghana must be transformed in ways that will enable students to acquire the creative thinking, flexible problem solving, collaboration and innovative skills they will need to be successful in work and life (Trilling \& Fidel, 2009; Riddle, 2009; Carroll, 2007). The use of ICT in teaching Social Studies will greatly contribute to the teaching and learning of social studies. Social Studies teachers will be able to teach the concepts and theories of Social Studies as well as organize and supervise class sessions, organize field trips, explain scientific observations to students and lead them to make valid and reliable conclusions.

While it is true that significant efforts have been made by the Government of Ghana through the Ministry of Education and the Ghana Education Service to integrate technologies in teaching and learning of social studies making the subject more fun to teach and learn, much however cannot be said regarding studies on the factors that are militating against the integration of ICTs in teaching social studies at basic schools within the Kwahu West Municipality of Ghana. The study therefore seeks to establish the major factors that are negatively affecting the integration of ICT in teaching and learning of social studies within the Kwahu West Municipality of Ghana.

\section{Statement of problem}

The use of ICT for teaching and learning is important since it guarantees unrestricted access to relevant information and development in subject areas as well as the provision of efficient and effective tools to take care of students' individual differences including people with special needs (Bede, Termit, \& Fong 2015). There are many efforts that have been made by the Government of Ghana to improve the integration of ICT in various subjects as seen in the 2007 educational reforms. The Education Strategic Plan (2003-2015) and (2010-2020) of the Ghana Education Service identified the need for ICT in education to help achieve the objectives of the Education Strategic Plan, which are carved into Access, Quality, Gender and Inclusiveness, and Education Management. On the basis of promoting ICT in education, the Ministry of Education launched the ICT in Education Policy in 2008 as a way of addressing the ICT needs in education.

Similarly, the Basic School Computerization policy was created in 2011 to introduce computers and elearning into the entire education system. Hence, in 2012, the Ministry of Education through rLG, an ICT company in Ghana introduced the "teacher laptop and ICT project" where teachers were trained in ICT and provided with laptops to aid in research, teaching and learning across a variety of subject areas. (Natia\& Al-hassan 2015).

One would have thought that with all these provisions, basic school teachers will effectively integrate ICT into their teaching and learning process. Indeed, the teaching Junior High School Social Studies Syllabus recommend teachers to integrate technology in the teaching of concepts as they handle certain topics in Social Studies (Curriculum Research and Development Division, 2007). But it appears the opposite exist within the Junior High Schools(JHS) in Ghana and specifically within Kwahu West Municipality leading to the increasing likelihood of Social Studies education becoming irrelevant to the interests and issues of pupils. There is therefore the need to study the factors that are working against the smooth integration of ICT into the teaching of social studies in the basic schools especially within the Kwahu West Municipality.

\section{Purpose of the study}

The main purpose of the study was to obtain evidence of the major factors that influence basic school social studies teachers' integration of ICT in the teaching and learning of social studies in the Kwahu West Municipality of Ghana.

The specific objectives of the study were to find out:

i. How ICT infrastructure (ICT resources) of schools influence social studies teachers' integration of 
technology in social studies lessons.

ii. How social studies teachers' ICT competence influence their integration of technology in social studies lessons.

iii. How social studies teachers' work load influence their integration of technology in social studies lessons.

\section{Research Hypotheses}

The following hypotheses were postulated for the study.

i. Ho: There is no significant difference among the factors ICT Infrastructure, ICT competencies and teachers' workload that influence JHS Social Studies teachers' integration of ICT in their social studies lessons.

H1: There is a significant difference among the factors ICT Infrastructure, ICT competencies and teacher's workload that influence JHS Social Studies teachers' integration of ICT in their social studies lessons.

\section{Significance of the study}

Limited researches exist in the areas of Junior High School Social Studies teacher education in Ghana, specifically on their integration of technology, pedagogy and content knowledge. The findings of this study will enable the government of Ghana and the Ministry of Education to pay more than the usual attention to the need to put in place functional ICT infrastructure in basic schools in the country. Also, the findings of the study will inform teacher training institutions in Ghana the need to introduce a course that will enable teacher trainees to acquire the requisite competencies, skills and knowledge to effectively integrate technology in their teaching and learning.

\section{LITERATURE REVIEW}

\section{The Concept of Technology Integration in Schools}

In the words of Cheryl A. Franklin and Cheryl Mason Bolick, technology has been viewed as a lodestone for improving student academic performance and for increasing the flexibility of schools and as a way to circumvent learning difficulties and to advance more efficient learning; it has been viewed as a means to provide access to learning outside classroom. (Franklin, C.\&Bolick, C. 2007). This is also true in the case of Ghana where it is common to see teachers giving out assignments to students and asking them to do further reading on the internet so as to be able to get answers to the assignments. We are certainly living in a technological age and this has differentiated teaching and learning in our era from those of the $18^{\text {th }}$ and $19^{\text {th }}$ centuries.

Defining technology integration is complicated and researchers have assumed multiple perspectives on this subject. (Michael, H. 2018). This is reflected in the different views researchers express on the meaning of the concept of technology integration. To some teachers, technology integration might mean utilization of the mostrecently developed technologies such as: tablets and wearable devices; implementing a one-to-one laptop initiative, where each student is provided with a laptop; development of daily lessons integrating an interactive whiteboard; or even the launch of online instructional programs that may substitute for the traditional textbook. To other teachers it may mean creating a PowerPoint to demonstrate an understanding of a concept, or it may mean taking the students to the computer lab once a week to work on a research project. Still other teachers may view technology integration as the use of the overhead, chalkboard or dry erase board, or textbooks with paper and pencil. (Michael, 2018)

According to his blog Education4site, Thayer (2011) as cited in (Michael, 2018) describes three uses of technology integration and argues that without considering each of the three one might miss the holistic intent and thus will have a limited picture and understanding of technology integration. The three "distinctly different aspects" are: Technology Integration in Learning (TiL), Technology Integration in the Classroom (TiC), and Technology Integration in Instructors' duties (TiI).

Williams (2003) describes ICT integration as the means of using ICT tools (internet, e-learning technologies, CD Rom etc) to assist teaching and learning. From this we can say that technology integration is the use of technology to enhance and support the educational environment, teacher instruction and student learning. The way in which educators infuse technology into teaching experiences of students. This is different from the usual technology use which is a concept that conveys the idea of using technology sporadically and largely by teaching staff to automate or digitize existing processes and is characterized by the situation where a lot of time is spent learning how to use the tech tool rather than using it to learn and the actual technology is peripheral to the learning process.

According to Okojie et al. (2006), "Technology integration not only involves the inclusion of technical artifacts per se, but also includes theories about technology integration and the application of research findings to promote teaching and learning" (p. 66). According to a study by Cuban et al., (2001), students' use of only applications, such as the Internet to conduct a simple search or Google to obtain images, represents a low degree of technological integration. In contrast, the development of multi-media presentations containing animation, 
video editing and completing projects that involve collecting and explaining data, represents a high degree of integration. Teachers who are exploring questions such as "How can one take what they already have and enhance it through the use of technology?" exhibit the type of thinking that might elevate technology integration to the next level (Cuban et al., 2001, p. 815).

This means that social studies teachers in basic schools cannot be content with just asking pupils to do research on the internet using search engines and then conclude that they integrate technology into their lessons. It is obvious from the point of view of Cuban et al that technology integration involves far more than that. The integration of technology goes beyond the utilization of a digital device, but rather it is a part of the instructional process and must be deliberate in how and why it is being used. The National Center for Educational Statistics (NCES) described technology integration in this way: "Effective integration of technology is achieved when students are able to select technology tools to help them obtain information in a timely manner, analyze and synthesize the information, and present it professionally." It continues to state that "the technology should become an integral part of how the classroom functions; as accessible as all other classroom tools" (NCES, 2008).

This more refined definition now considers not only the perceptions of the teacher, but also includes the role of the student in accessing and using technology. This agrees with Mishra and Koehler (2009) who subscribe that "Technology integration approaches that do not reflect disciplinary knowledge differences, the corresponding processes for developing such knowledge, and the critical role of context ultimately are of limited utility and significance, as they ignore the full complexity of the dynamic realities of teaching effectively with technology" (p. 58). We cannot help but agree that rapid improvement in educational technologies exceed the current knowledge of effective computer technology use in education (Allen 2001). The need for teachers to acquire more knowledge on how to integrate technology into their teaching is reflected in the words of Agyei:

"Continuous in-service training should be provided for subject matter teachers, possibly through their various subject association to evaluate and use digital resources in the teaching learning process (Agyei, 2013),

\section{Factors that influence technology integration}

Technology integration is not a spur of a moment event. It does not just happen in a vacuum. Technology integration is affected by several factors. Buabeng-Andoh (2012) and D.D Agyei (2013) both identified several of these factors that influence teacher's decision to integrate technology in their teaching. This study reviews three major factors that influence technology integration as supported by relevant literatures.

\section{Availability of infrastructure to support ICT}

To support ICT integration in schools, the whole prerequisite hardware infrastructure needs to be in place with the supporting elements such as electricity, maintenance, and technical services (Sahoo, 2019). Without electricity connectivity in basic schools, it will be impossible to use desktop computers. Even with the supply of laptops to basic schools, they have to be regularly charged since the battery life of the laptops in our basic schools will not be over an hour of continuous use. Another important infrastructure needed for the integration of ICT in the teaching of social studies in our basic school is the availability of computers. It is for this reason that the government of Ghana has taken the needed steps to provide computers to pe-teriary schools in the country. For example, Agyei and Voogt (2011a, 2011b) as cited in Agyei (2013) reported that the government of Ghana and other institutions have invested huge sums of money in procurements of computers and establishment of computer labs in most secondary institutions following the introduction of ICT into the school curriculum in September 2007. The e-readiness survey conducted by the Ministry of Education sought to provide validated data that informs on the categorization of secondary schools, and on issues that need to be addressed in planning for the deployment of ICTs to schools (MOE, 2009). The report showed that $87 \%$ of all secondary institutions are reported as having at least one computer laboratory.

Even though their study focused on Senior High Schools, same can be said that Junior High Schools in Ghana have been provided with laptop computers to foster the teaching of ICT as a subject on the school curriculum as well as the quest to integrate ICT in teaching and learning. It could also be said that teachers in most Junior High Schools in the country have benefited from the supply of laptops under a special programme by the government of Ghana to promote teaching and electronic learning (e-learning) in basic schools.

Mireku et al. (2009) reported as cited in Agyei (2013) that at the pre-tertiary level, the few computers that the schools have are easily broken because of lack of air-conditioners, unstable electrical power supply, and virus infections. Based on the data collected, the average ratio of students to computers at the national level is $42: 1$. There is no study on the ratio of students to computers at the basic school level in our country but one can conclude base on the huge enrollments in our basic schools that pupil ratio to a computer at the basic level will be far more than $42: 1$. The importance of availability of computers to the integration of ICT into the teaching and learning of social studies in basic schools can never be underestimated.

An equally important element relating to ICT infrastructure is internet accessibility connectivity. Social 
studies teachers in our basic schools need internet connectivity to do download of videos, audios and images in the quest to integrate ICT into their teaching. However, internet accessibility and connectivity are a luxury enjoyed only by people living in the cities. Most of the schools in the rural areas of Ghana do not have reliable internet connectivity.

According to Agyei (2013), network related challenges include a lack of connectivity, frequent internet breakdown/disruptions, and high down-time of equipment in both secondary institutions and teacher education institutions in Ghana. For example, the e-readiness report cited in D.D Agyei (2013) indicated that of the 501 secondary schools, only 111 had local area networks in place and 390 did not. With regards to internet access, 89 representing $17.7 \%$ of the total number of schools had internet.

Junior High Schools in Ghana cannot boost of state-of-the-art computer laboratories. In the schools that have computers, these computers are kept at the head teacher's office and are only brought to the classrooms during ICT lessons. The lack of network accessibility and connectivity in basic schools in Ghana has serious implication for both teachers and students. As a result of this, social studies teachers are not able to use technologies which depend on the internet to enhance their pedagogical content knowledge in the integration of technology in the teaching and learning of social studies. Their students are also not able to use the internet to construct knowledge on their own both in and outside the classroom. What this means is that the country is unable to fully position itself to benefit from the affordances of technology for the $21^{\text {st }}$ teaching paradigm. There is therefore an urgent need for the government and powers that be to pay more than the usual lips services to the provision of technological infrastructure at the basic schools in the country so as to support teachers and students in using the internet fully in the teaching and learning process.

\section{Teacher competence and technology integration}

As indicated in Bordbar 2010, teachers' computer competence is a major predictor of integrating ICT in teaching. This cannot be otherwise because we give what we have. We cannot be talking about teachers integrating ICT into their lessons when these teachers have no knowledge or competence on the technologies to talk less about how to combine them with their lessons. The recent education reforms launched in June 2007 called for the introduction of information and communications technology (ICT) at the secondary institutions through:

i. $\quad$ The introduction of ICT as a core subject;

ii. The introduction of ICT as an elective subject;

iii. The integration of ICT as a teaching tool for all subject areas; and

iv. The integration of ICT to support educational management and administrative functions.

To integrate ICT into the teaching of social studies in our basic schools calls for a particular kind of teacher knowledge knows as technological pedagogical content knowledge (TPACK) Technological pedagogical content knowledge refers to the integration of appropriate technological tools in teaching a content of a topic. The integration of ICT as a teaching tool for all subject areas is not a common practice because ICT teachers do not have the levels of competence (pedagogical combination with technological skills) to enable them to use ICT tools and equipment in the teaching and learning process. (Agyei, 2013) This contention has been corroborated by a number of studies (Agyei, 2012; Agyei \&Voogt, 2011a; Mereku et al., 2009; MOE, 2009; Ottevanger, \& de Feiter, 2007 ) conducted in Ghana to analyze the experiences of teachers to integrate ICT in teaching.

In a report on e-Readiness Assessment conducted by the Ministry of education in Ghana in 2009 as cited in Agyei 2013 only 9.4\% Senior High school teachers of the 17,953 total teaching staff was ranked as having integration skills, indicating that very few teachers were using available ICT facilities to teach other subject areas, or had the skills to do so. According to Becta (2004), lack of ICT concentration in initial training is a barrier to teachers' use of ICT in integrating it in the subject matter. Therefore, where there is no effective training on ICT, teachers will not be able to use ICT resources for integration purpose.

Unfortunately, the pre-service teacher training programs of Colleges of Education and Teaching Universities that are offering top-up programs in the country for teachers in the basic schools through the distance education and sandwich modules provide little opportunity for trainees to learn skills necessary to integrate ICT into teaching. Research has shown that such programs have not adequately modeled the use of technology in their method courses or incorporated effective approaches to technology integration into a single technology courses (cf. Brown \&Warschauer, 2006 as cited in Agyei 2013). Accordingly (Osborne \& Hennessy, 2003) indicated that new ICT tools and teaching call for the training of teachers. Social studies teachers' ICT skill and access to professional development is very critical to their competence in the integration of ICT in their lessons. Training helps to equip people with current skills in the performance of their duties. So, if social studies teachers of the $21^{\text {st }}$ century have to cope with the technologies of our era, they need to be trained on their uses.

When social studies teachers are not well trained on how to integrate the new technologies in their lessons, they will not be competent and confident enough to carry out an all-out integration of ICT in their lessons. This is in agreement with Luhombo (2015) who asserted that the success of integrating ICTs into teaching and learning in developed and developing countries like Kenya depends on how teachers have been prepared to use computers. 
He added that since teachers are the backbone in curriculum implementation and integrating computers in schools, they should be trained properly in the use and integration of computers in teaching and learning. When properly trained, teachers' ability to select, integrate and evaluate computer tools to support teaching and learning will improve he concluded.

\section{Teachers' workload}

Samarawickrema \& Stacey (2007) cited in Buabeng-Andoh (2012) investigated factors related to the use of learning management system in a large multi-campus urban university in Australia. They adopted case study method and purposive sampling to select 22 participants used web-based methods to teach both on- and offcampus students for the study. The findings of the research found that increased workload coupled with teaching with technology was critical to the participants of the study. Factors reported to contribute to increased workload were course maintenance and constant upgrades, student emails, the learning of new skills and the continuous search of sustainable strategies.

Also, Buabeng-Andoh (2012 reported that Abuhmaid (2011) conducted study on the conduct and effectiveness of ICT training courses within the Jordanian education system. The sample population was 115 teachers and 12 school principals. Interviews, questionnaires, direct classroom observations, and field-notes of classroom practices were used for data collection. In the study, one principal reported that "teachers are already overloaded; they could not cope with the pressure from ICT training" (p.12). In addition, a teacher stated that "teachers are overloaded to learn, prepare and practice what they learn"

Accordingly, Ely (1999) cited in Luhombo (2015) investigated that ICT integration is likely to fail due to lack of time to prepare ICT teaching materials due to loaded curriculum. Teachers feel that infusing ICT in teaching is an added load. All of these findings tell us that teachers' workload have a great influence on teachers' decision to integrate technology into their teachers. Teachers already have a lot at their hand. They have to devote a lot of time to reading for their lessons, writing of weekly lesson notes, marking of students' exercises and assignments which they sometimes have to painfully bring home to complete. On top of these, they have to give remedial teaching, participate in the school's extra curriculum activities, offer counseling programs to their students and attend to other duties as may be assigned to them by their heads of schools. The preparations that go into the decision to integrate technology into social studies lessons can be so enormous that combining it with routine tasks of teachers may be overwhelming. It is likely that teacher may relegate the integration of technology into their teaching if they see it as burden and an extra load on their already heavy workload.

\section{Theoretical framework}

The study is based on Everett Rogers' Diffusion of Innovations theory (Rogers, 2003). Diffusion of innovation is a theory that seeks to explain how, why, and at what rate new ideas and technology spread through cultures. Rogers argues that diffusion is the process by which innovation is communicated over time among the participants in a social system. Rogers' Diffusion of Innovation theory is the most appropriate for investigating the adoption of technology in higher education and educational environments (Medlin, 2001; as cited in Luhombo, 2015.)

Diffusion (spread) of Innovations theory takes a different approach compared to other theories of integration. Instead of focusing on persuading individuals to change, it sees integration as primarily being about the evolution or "reinvention" of products and behaviors" so as to fit better for the individual or as a group. Rogers proposes that four main elements influence the spread of a new idea. These he said are: the innovation itself, communication channels, time and a social system. The end of this diffusion is that people are part of a social system adopt a new idea, behavior or product. Adoption means that a person does something differently than what they had previously. The key to adoption is that the person must perceive the idea, behavior or product as anew or innovative. It is through this that diffusion is possible.

Adoption of a new idea, behavior or product does not just happen simultaneously in a social system. Rather it is a process whereby some people are more apt to adopt the innovation than others. The stages by which a person adopts an innovation and whereby diffusion is accomplished include awareness of the need for an innovation, decision to adopt (or reject) the innovation, initial use of the innovation to test it and continual use of the innovation. There are five main factors that influence adoption of an innovation and they are:

i. Relative advantage. The degree to which an innovation is seen as better than the idea, program or product it replaces.

ii. Compatibility. How consistent the innovation is with the values, experiences and the needs of the potential adopters.

iii. Complexity. How difficult the innovation is to understand and /or use

iv. Inability. The extent to which the innovation can be tested or experimented with before a commitment to adopt is made

v. Observability. The extent to which the innovation provides tangible results. 


\section{CONCEPTUAL FRAMEWORK}

In this study, the researcher identified major factors that that influence basic school social studies teachers' integration of technology in their teaching of social studies. The descriptive survey design was used to explain the relationship between the independent variables and the dependent valuables and shows how the independent variables influence the dependent variable. In the study, the dependent variable was technology integration for the teaching of social studies at basic schools in the Kwahu West Municipality of Ghana. The independent variables were ICT infrastructure, Teachers' ICT competence and teachers' work load.

Each of these three variables had its indicators as shown in the figure 1.

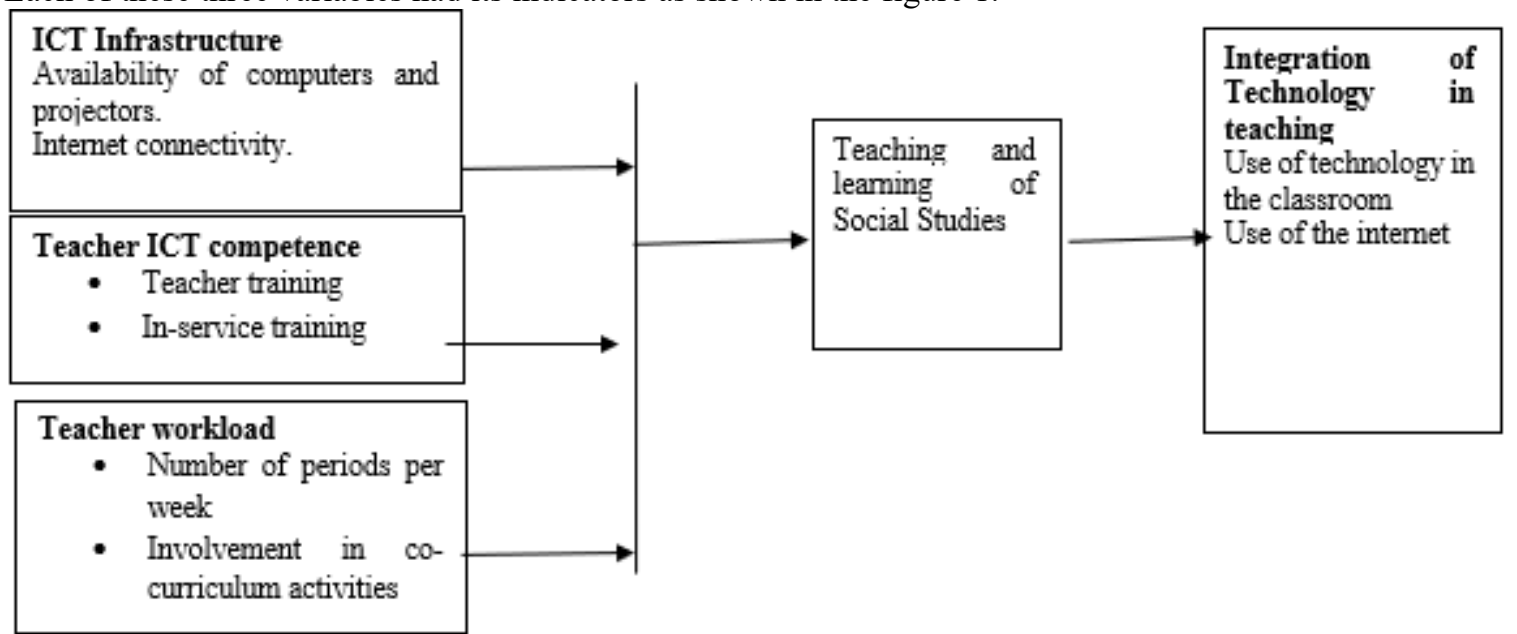

From the diagram, effective integration of technology is as a result of the availability of ICT infrastructure such as computers and electricity, teacher competence which can be achieved through teacher training programs and in-serve training that will adequately equipped teachers to handle their workloads. It is envisaged that all of this will result in change in teaching methods as teachers will be able to use technology in their classrooms.

\section{METHODOLOGY}

\section{Research design}

The research design deemed appropriate for this study was descriptive survey. According to Best and Khan (1995), descriptive research is concerned with the conditions or relationships that exists, such as determining the nature of prevailing conditions, practices and attitudes, opinions that are held; processes that are going on; or trends that are developed. The design provides an accurate picture of events by explaining people's perception and behaviour on the basis of data gathered at a particular time (Amedahe. 2002). Based on these unique features of the descriptive research design, the researcher chose the descriptive survey design to answer the research question concerning the current status of social studies teachers' technology integration in their teaching and learning of social studies lessons in the Kwahu West Municipality.

\section{Population, Sampling Size and Sampling Technique of the Study}

The target population of the study consisted of all Junior High School (JHS) Social Studies teachers teaching at the Kwahu West Municipality in the 2017-2018 academic year. The justification for this population was their relatedness and significance to the problem identified within the Kwahu West Municipality. The sample size for the study was eighty-one (81) JHS Social Studies teachers. The researcher employed proportional simple random technique in selecting the Social Studies teachers from the selected Junior High Schools within the Kwahu West Municipality. According to Krejcie and Morgan (1970) a population of ninety-seven (97) will use seventy-nine (79) as the sample size but in order to increase the return rate the researcher used a sample size of eighty-one (81) Social Studies teachers. The simple random lottery method without replacement was used to select the required sample size. In all eighty-one (81) JHS Social Studies teachers were selected from 46 public basic schools within the Kwahu West Municipality of Ghana for the study.

\section{Instrumentation and Data Collection Procedure}

A survey questionnaire was developed by the researcher in line with relevant literature on the study and the objectives of the study to collect data for the study.

The questionnaire was developed particularly for the Junior High School social studies teachers to elicit their responses on how ICT infrastructure, teachers' competence and teachers' workload affect their integration of technology in their teaching of social studies. To ensure the reliability of the instruments, the researcher pilot tested the questionnaire on twenty (20) Junior High School Social Studies teachers in seven (7) selected Junior High 
Schools in the Ashanti-Akim Central Municipality. Specifically, Agogo L/A 2 School, Ramseyer Preparatory School, Ebenezer preparatory school, St Anthony School, Islamic Basic School, Apostolic D/A Basic School and Brako preparatory school.

The justification for the selection of these schools is based on the fact that these schools shared similar characteristics with the Junior High Schools in the Kwahu West Municipality. The pilot test also helped in testing the consistency of the questions with data analysis techniques. The pilot test further helped in refining and rewording ambiguous statements and the order of questions restructured. The Cronbach alpha was used to test for the reliability of the items on the questionnaire were measured on a four-point scale. $1=$ strongly disagreed, $2=$ disagree, $3=$ agreed and $4=$ strongly agreed. The Cronbach alpha value of .860 was obtained on the questionnaire. According to De Vellis (1991) the coefficient obtained is very respectable and capable of helping the researcher to obtain the relevant data is above 0.70 . Undoubtedly the item had the potential of eliciting the desired information as expected.

The questionnaire was personally administered by the researcher to the respondents. Before and during the administration of the questionnaire to the teachers, ethical issues such as informed consent, right to privacy, voluntary participation, anonymity and confidentiality were fulfilled to the later.

\section{Data processing and analysis}

The data analysis phase of the study consisted of editing, coding and statistical computation. After the data collection, the terms were labeled serially to ensure easy identification, error and easy coding. The data gathered was then analysed with the aid of statistical packages for social science (SPSS version 21). Inferential statistics i.e. Multiple Linear Regression Analysis was used to test the hypothesis. This is because it is a multivariate technique for determining the correlation between a criterion variable (dependent) and a combination of two or more predictor variables (independent). It is used for predicting a dependent variable from two or more optimally combined independent variables. Before employing the multilinear regression model the researcher ensured that the following assumptions were satisfied:

i. Reliability of the measures was high.

ii. Variables are normally distributed since Multi linear regression analysis requires all variables to be multivariate normal. This assumption was checked with a histogram and a fitted normal curve.

iii. Also, linearity assumption was tested with scatter plot to check for outliners since multiple regression is sensitive to outlier effects.

iv. There was a check to ensure that there was no or little autocorrelation in the data. Autocorrelation was tested with the Dubin-Watson test at a value of 1. 732. According to Etsey (2014), a value of 1.5 $<\mathrm{d}<2.5$ indicates that there is no autocorrelation in the multiple linear regression data.

\section{Discussion of results}

H0: There is no significant difference among the factors ICT Infrastructure, ICT competencies, and teachers' workload that influence JHS Social Studies teachers' integration of ICT in their social studies lessons.

H1: There is a significant difference among the factors ICT Infrastructure, ICT competencies, and teacher's workload that influence JHS Social Studies teachers' integration of ICT in their social studies lessons

The main aim of this hypothesis is to test whether there is any statistically significant difference among factors that influence JHS Social Studies teachers' technology, content and pedagogy integration. Standard multiple regression was conducted to determine the accuracy of the independent variables predicting teacher's technological integration.

The results are presented in Table 1. 
Table 1- Multiple Regression Analysis.

\begin{tabular}{|c|c|c|c|c|c|}
\hline \multirow[t]{2}{*}{ Variable } & \multicolumn{2}{|c|}{$\begin{array}{l}\text { Unstandardized } \\
\text { Coefficients }\end{array}$} & \multirow{2}{*}{$\begin{array}{c}\text { Standardized } \\
\text { Coefficients } \\
(B)\end{array}$} & \multirow[b]{2}{*}{ t-value } & \multirow[b]{2}{*}{$\mathrm{p}$-value } \\
\hline & $\mathrm{B}$ & Std. Error & & & \\
\hline (Constant). & 24.493 & 4.420 & & 4.772 & 0.000 \\
\hline ICT infrastructure & .712 & 295 & .343 & 2.414 & 0.000 \\
\hline ICT competencies & .655 & 297 & .230 & 1.533 & 0.002 \\
\hline Work load & .578 & .306 & 264 & 2.479 & 0.001 \\
\hline Multiple R value & $.842 a$ & F value & 7.104 & & \\
\hline R Square value & .709 & $P$ value & $0.004 \mathrm{a}$ & & \\
\hline Adjusted R Square & .286 & Durbin-Watson & 1.732 & & \\
\hline
\end{tabular}

a. Predictors: (Constant), ICT Infrastructure, ICT competency, teachers' workload

b. Dependent Variable: Technology Integration

Source: Field Survey, Afutor (2018) $\quad *$ Significant, $\mathrm{p}<0.05$

As depicted in the Table 1, the overall significance of the standard multiple regression model is shown in the F-change statistic $=7.104 ; p=0.004$. The regression model is significant given the level of significance 0.004 which is less than 0.05 ; therefore, there is statistically significant difference between the means of the dependent and independent variables. The value of F-test disclosed that the model is satisfactory. The Durbin-Watson test statistic tests the null hypothesis that the residuals from an ordinary least-squares regression are not auto correlated. Since the DW value of 1.732, then it was concluded that there was no autocorrelation among the model residual.

As evident in Table 1, the multiple correlation coefficients is 0.842 and it measures the degree of relationship between the actual values (ICT Infrastructure, ICT competencies, and teachers' workload) and the predicted value of technology integration. The coefficient value of 0.842 indicates that the relationship between the independent variables (ICT Infrastructure, ICT competencies, and teachers' workload) and dependent variable (technology integration) was very high and positive. The coefficient of determination (R-square) was also carried out to measure the goodness-of-fit of the estimated standard multiple regression in terms of the proportion of the variation in the dependent variables explained by the fitted sample regression equation. The study established $\mathrm{r}^{2}=0.709$ Thus, the value of $\mathrm{r}^{2}$ of 0.709 indicates that about $70.9 \%$ of the variations in technology integration was explained by the estimated standard multiple regression which involves ICT infrastructure, ICT competencies and teachers' workload on technology integration as the independent variables and $r^{2}$ value is significant at five percent level.

This implies that the independent variables account for only $70.9 \%$ of factors that affect the dependent variable. From Table 1, the constant of the regression model was 24.493 which suggest that even when the independent variables were zero still technology integration among respondents would be 24.493 .

Again, the coefficient of ICT infrastructure, ICT competence and teachers' workload on technology integration as factors was $0.712 ; 0.655 ; 0.578$ respectively representing the partial effect of the independent variables on technology integration among respondents. The positive signs implies that such effect is positive and that technology integration among respondents would increase by 0.712 and 0.655 and decrease by 0.578 for every unit increase in the independent variables respectively.

Taking the independent predictors into account, a p-value $(0.000)$ indicates that the JHS Social Studies teacher's integration of technology, content and pedagogy is significantly related to the ICT infrastructure in their schools. These two factors are positively correlated. The relationship means that the greater the accessibility to ICT facilities, the higher the JHS Social Studies teacher's integration of technology, content and pedagogy. Also, a p- value (0.002) also depicts that JHS Social Studies teacher's integration of technology, content and pedagogy significantly related to the ICT competency. These two factors are also positively correlated. The relationship means that the higher the level of competency of JHS Social Studies teachers the greater the integration of technology, content and pedagogy.

\section{Conclusion}

Integration of technology by Social studies teachers in the Kwahu West Municipality is heavily influenced by the ICT infrastructure in their schools, teachers' competence and their work load.

\section{RECOMMENDATION}

Firstly, it is recommended that the Government of Ghana through Ministry of Education and other relevant stakeholders should ensure the provision of art-of-craft ICT infrastructure in basic schools within the municipality to enhance social studies teachers' integration of technology into the teaching and learning of the subject to prepare learners for $21^{\text {st }}$ century world.

Secondly, it is recommended that Social Studies specialists in technology integration within the Eastern Region should organize regular in-service training programs for Junior High Social Studies teachers in the Kwahu West Municipality to enable them effectively use technological resources to enhance their content delivery of 
Social Studies lessons.

Lastly, in order to ensure effective integration of technology, headteachers of Junior High Schools in the Kwahu West Municipality should reduce the workload of Social Studies teachers. Social studies teachers should not be given other subjects to teach, their participation in co-curriculum activities such as training the school's sport teams and being in charge of the school garden should be significantly minimized. This will motivate Social Studies teachers to use the spare time to prepare for the processes that are involved in integrating technology into their social studies lessons.

\section{REFERENCES}

Abuhmaid, A. (2011). ICT training courses for teacher professional development in Jordan. Turkish Online Journal of Educational Technology-TOJET, 10(4), 195-210.

Agyei, D. D. (2012). Preparation of Pre-service Teachers in Ghana to integrate Information and Communication Technology in teaching Mathematics. Enschede, The Netherlands: University of Twente.

Agyei, D. D., \& Voogt, J. (2011a). ICT use in the teaching of mathematics: Implications for professional development of pre-service teachers in Ghana. Education and Information Technologies, 16(4), 423-439.

Agyei, D. D., \& Voogt, J. (2011b). Exploring the potential of the Will Skill Tool model in Ghana: Predicting prospective and practicing teachers' use of technology. Computers \& Education, 56(1), 91-100.

Agyei, D. D., \& Voogt, J. (2012). Developing technological pedagogical content knowledge in pre-service mathematics teachers through collaborative design. Australasian journal of educational technology, 28(4).

Agyei, D. D. (2014). Analysis of technology integration in teacher education in Ghana. Pedagogy, 8(1), 5.

Allen, R. (Fall 2001). Technology and learning: How schools map routes to technology's promised land. ASCD Curriculum Update,vol.1-3,pp.6-8.

Amedahe, F. K. (2002). Fundamentals of educational research methods. Mimeograph, UCC, Cape Coast.

Becta (2003). What research says about barriers to use of ICT in learning? From <www.becta.uk/research> retrieved on 25 , October 2018

Bede, B.C.O., Termit, K.R.S., \& Fong, S.F. 2015. "Need for ICT integration for effective instructional delivery in Nigerian Colleges of Education". Journal of Education and Practice, Vol. 6, no. 3, pp. 51-56.

Best, J. \& Kahn, J.V. (2006).Research in Education (10thed.). Boston: Allyn and Bacon

Bordbar, F. (2010). English teachers' attitudes toward computer-assisted language learning. International Journal of Language Studies, vol. 4, no. 3, pp. 27-54

Brown, D., \&Warschauer, M. (2006). From the university to the elementary classroom: Students' experiences in learning to integrate technology in instruction. Journal of Technology and Teacher Education, 14(3), 599621.

Buabeng-Andoh, C. (2012). An Exploration of Teachers' Skills, Perceptions and Practices of ICT in Teaching and Learning in the Ghanaian Second-Cycle Schools. Contemporary Educational Technology, 2012, 3(1), 36-49.

Carroll, J., \& Ryan, J. (Eds.). (2007). Teaching international students: Improving learning for all. Routledge.

CRDD - Curriculum Research and Development Division (2007). Teaching Syllabus for Junior High School Social Studies Accra, Ghana: Ministry of Education Science and Sports.

Cuban, L., Kirkpatrick, H., \& Peck, C. (2001). High access and low use of technology in high school classrooms: Explaining an apparent paradox. American Educational Research Journal, 38(4), 813-834.

DeVellis, R. F. (1991). Applied social research methods.

Duch, B. J., Groh, S. E., \& Allen, D. E. (2001). The power of problem-based learning: a practical" how to" for teaching undergraduate courses in any discipline. Stylus Publishing, LLC..

Dunmire, R. E. (2010). The use of instructional technology in the classroom: selection and effectiveness. United States Military Academy, New York: Unpublished Master's Thesis.

Etsey, Y.K.A (2014) EPS 851 Intermediate educational statistics: Course Pak

Franklin, C.\&Bolick, C. (2007). Teaching Teachers to Use Digital Primary Source Materials in Social Studies: A Symposium, Part 1. In Society for Information Technology \& Teacher Education International Conference (pp. 4088-4092). Association for the Advancement of Computing in Education (AACE).

Friedman, A., Bolick, C., Berson, M., \&Porfeli, E. (2009). National educational technology standards and technology beliefs and practices of social studies faculty: Results from a seven-year longitudinal study. Contemporary Issues in Technology and Teacher Education, 9(4), 476-487.

Hardisky, M. (2018). TPACK: Technology integration and teacher perceptions. Drexel University.

Hooper, S., \&Rieber, L. P. (1995). Teaching with technology. Teaching: Theory into practice, 2013, 154-170.

ICT in education Policy (2015) . Ministry of Education

Koehler, M., \& Mishra, P. (2009). What is technological pedagogical content knowledge (TPACK)?. Contemporary issues in technology and teacher education, 9(1), 60-70.

Luhombo, C. S. (2015). Teacher factors influencing integration of information communication technology in teaching Of English in public secondary schools in Mumias sub county, Kenya (Doctoral dissertation, 
University of Nairobi).

Medlin, B. D., Dave, D. S., \&Vannoy, S. A. (2001). Students' Views of the Importance of Techncal and NonTechnical Skills for Successful it Professionals. Journal of Computer Information Systems, 42(1), 65-69.

Mereku, D. K., Yidana, I, Hordzi, W., Tete-Mensah, I., Tete-Mensah, W., and Williams, J. B. (2009). Pan African Research Agenda on the Pedagogical Integration of ICTs: Ghana Report. Retrieved from http://www.ernwaca.org/panaf/pdf/phase-1/Ghana- PanAf Report.pdf on April 17, 2018.

Ministry of Education (MOE). (2009). Report on e-Readiness Assessment of Second Cycle Institutions in Ghana. Accra, Ghana: ICT in Education Programmes Unit, Ministry of Education.

Mishra, P., \& Koehler, M. J. (2006). Technological pedagogical content knowledge: a framework for integrating technology in teacher knowledge. Teachers College Record, 108(6), 10171054

Natia, J. A \& Al-hassan ,S. (2015) Promoting teaching and learning in Ghanaian Basic Schools through ICT International Journal of Education and Development using Information and Communication Technology Vol. 11(2), pp. 113-125

NCES. (2008). Technology in Schools. Retrieved October 27, 2018, from https://nces.ed.gov/pubs2003/tech_schools/chapter7.asp

Okojie, M. C., Olinzock, A. A., \&Okojie-Boulder, T. C. (2006). The Pedagogy of Technology Integration. The Journal of Technology Studies, 32(2), 66-71

Osborne, J., \& Hennessy, S. (2003). Literature Review in Science Education and the Role of ICT: Promise. Problems and Future Directions, Bristol: United Kingdom.

Ottevanger, W., van den Akker, J., \& de Feiter, L. (2007). Developing Science, Mathematics, and ICT Education in Sub-Saharan Africa: Patterns and Promising Practices. C) Washington, DC: World Bank. Human Development Department.

Papaioannou, P., \& Charalambous, K. (2011). Principals' attitudes towards ICT and their perceptions about the factors that facilitate or inhibit ICT integration in primary schools of Cyprus. Journal of Information Technology Education: Research, 10(1), 349-369.

Riddle, G. (2009). U.S. Patent No. 7,545,748. Washington, DC: U.S. Patent and Trademark Office.

Rogers, E.M. (2003). Diffusion of innovations. New York: Free Press

Sahoo, R. K. (2019). Exploring the Changes in Teaching Strategies Enabled by Information and Communication Technology. International Journal of Theory and Application in Elementary and Secondary School Education, 1(2), 75-91.

Samarawickrema, G. \& Stacey, E. (2007). Web-based learning and teaching: A case study in higher education Distance Education, vol. 28, no. 3, pp. 313-333.

Schwab, K. (2015). The Fourth Industrial Revolution: What It Means and How to Respond. Retrieved from: https://www.foreignaffairs.com/articles/2015-12-12/fourthindustrial- revolution

Thayer, A., Lee, C. P., Hwang, L. H., Sales, H., Sen, P., \&Dalal, N. (2011, May). The imposition and superimposition of digital reading technology: the academic potential of e-readers. In Proceedings of the SIGCHI Conference on Human Factors in Computing Systems (pp. 2917-2926).

Trilling, B., \& Fadel, C. (2009). 21st century skills: Learning for life in our times. John Wiley \& Sons. 